\title{
Polymorphisms in the CIITA -168A/G (rs3087456) and CIITA +1614G/C (rs4774) may influence severity in multiple sclerosis patients
}

\author{
Os polimorfismos no gene CIITA -168A/G (rs3087456) e CIITA +1614G/C (rs4774) podem \\ influenciar a gravidade em pacientes com esclerose múltipla \\ Valéria Coelho Santa Rita Pereira1', Fabrícia Lima Fontes-Dantas², Eduardo Ribeiro Paradela², Fabiola \\ Rachid Malfetano', Simone de Souza Batista Scherpenhuijzen', Letícia Fêzer Mansur², Ronir Raggio Luiz', \\ André Peres De Oliveira², João Gabriel Dib Farinhas ${ }^{2}$, Ângelo Maiolino', Soniza Vieira Alves-Leon ${ }^{1,2}$
}

\begin{abstract}
It is currently unknown how genetic factors may influence the clinical course of multiple sclerosis (MS). Objective: We examined the impact of CIITA polymorphisms -168A/G (rs3087456) and +1614G/C (rs4774) on the risk of disability progression, severity and on responses to first-line immunomodulator treatments. Methods: Genomic DNA was extracted from blood samples. We used ABI3730xl and GeneMapper v.4.0 software to identify genotype variations. All patients were followed up and clinically reassessed at three-month intervals. Disability progression was measured by the Expanded Disability Status Scale and disease severity by the Multiple Sclerosis Spasticity Scale (MSSS). Results: We included 37 men and 80 women. We found no evidence regarding the influence of the single nucleotide polymorphisms studied in the Expanded Disability Status Scale or therapeutic response of the evaluated drugs. We performed a logistic regression analysis with the MSSS and found that a less severe MS course was associated with wild type CIITA -168AA and CIITA +1614GG, as the chance of the patient progressing to MSSS2 and MSSS3 decreased in $61 \%$ and $75 \%$ with CIITA -168AA and $66 \%$ and $75 \%$ with CIITA $+1614 \mathrm{GG}$, respectively $(p<0.0001)$. Although less significant, the CIITA +1614 GC also pointed to a less severe MS course and the chance of the patient progressing to MSSS3 decreased 79\% ( $p=0.015)$. We also observed that the CIITA -168GG genotype was more frequent in MSSS2 and MSSS3 and had 40\% lower odds ratio to becoming more severe MS. Conclusion: These data suggest that CIITA -168AA, CIITA +1614GG and CIITA +1614 GC polymorphisms may be associated with a better MS clinical course. This knowledge may be useful for a better understanding of MS and its therapeutic management.
\end{abstract}

Keywords: Multiple sclerosis; Polymorphism, Genetic; Therapeutics; Disease progression.

\section{RESUMO}

Atualmente não se sabe como os fatores genéticos podem influenciar o curso clínico da esclerose múltipla (EM). Objetivo: Examinamos o impacto dos polimorfismos CIITA -168A/G (rs3087456) e CIITA +1614G/C (rs4774) no risco de progressão da incapacidade, gravidade e resposta aos tratamentos imunomoduladores de primeira linha. Métodos: O DNA genômico foi extraído de amostras de sangue. Utilizamos o software ABI3730xl e GeneMapper v.4.0 (Applied Biosystems) para identificar variações genotípicas. Todos os pacientes foram acompanhados e reavaliados clinicamente em intervalos de três meses. A progressão da incapacidade foi medida pela EDSS e a gravidade da doença pelo MSSS. Resultados: Incluímos 37 homens e 80 mulheres. Não encontramos evidências sobre a influência dos SNPs estudados no EDSS e na resposta terapêutica aos fármacos avaliados. Realizamos uma análise de regressão logística com o MSSS e observamos uma evolução menos grave da EM associada aos tipos selvagens CIITA -168AA e CIITA +1614GG, pois a chance do paciente atingir MSSS2 e MSSS3 diminuiu em 61\%/75\%, e 66/75\% respectivamente ( $p<0,0001$ ). Embora menos significativo, o CIITA +1614GC também foi relacionado com evolução menos grave da EM e a chance do paciente atingir o MSSS3 diminuiu 79\% ( $p=0,015)$. Nós também observamos que o genótipo CIITA -168GG foi mais frequente no MSSS2 e MSSS3 e teve uma razão de chance 40\% menor para atingir forma mais grave da EM. Conclusão: Estes dados sugerem que os polimorfismos CIITA -168AA, CIITA +1614GG e CIITA +1614GC podem estar associados a um melhor curso clínico da EM. Este conhecimento pode ser útil para uma melhor compreensão da EM e o seu manejo terapêutico.

Palavras-chave: Esclerose múltipla; Polimorfismo genético; Terapêutca; Progressão da doença.

\footnotetext{
'Universidade Federal do Rio de Janeiro, Departamento de Neurologia, Rio de Janeiro RJ, Brasil.

${ }^{2}$ Universidade Federal do Estado do Rio de Janeiro, Laboratório de Neurociências Translacional, Programa de Pós-Graduação em Neurologia, Rio de Janeiro RJ, Brasil. Valéria Coelho Santa Rita Pereira (iD https://orcid.org/0000-0002-7212-5043; Fabrícia Lima Fontes-Dantas (iD https://orcid.org/0000-0002-5201-0927; Eduardo Ribeiro Paradela iD https://orcid.org/0000-0003-4048-3900; Fabíola Rachid Malfetano iD https://orcid.org/0000-0002-8275-3801; Simone de Souza Batista Scherpenhuijzen (iD https://orcid.org/0000-0002-3555-5693; Letícia Fêzer de Souza Mansur Zogbi (iD) https://orcid.org/0000-0001-9728-7279; Ronir Raggio Luiz (iD https://orcid.org/0000-0002-7784-9905; André Peres de Oliveira iD https://orcid.org/0000-0002-3379-8632; João Gabriel Dib Farinhas (iD https://orcid.org/0000-0001-8246-7891; Ângelo Maiolino (iD) https://orcid.org/0000-0003-0140-9548; Soniza Vieira Alves-Leon (iD) https://orcid.org/0000-0002-1538-6730
}

Correspondence: Soniza Vieira Alves Leon; Departamento de Neurologia, Hospital Universitário Clementino Fraga Filho-HUCFF, Universidade Federal do Rio de Janeiro-UFRJ; Rua Professor Rodolpho Paulo Rocco, 255 - Cidade Universitária; 21941-913 Rio de Janeiro RJ, Brasil; E-mail: sonizavleon@globo.com Conflict of interest: There is no conflict of interest to declare.

Support: This study was funded by support from the Conselho Nacional de Desenvolvimento Científico e Tecnológico (CNPq-Brazil), Coordenação de Aperfeiçoamento de Pessoal de Nivel Superior (CAPES-Brazil).

Received 25 June 2018; Received in final form 22 October 2018; Accepted 29 November 2018. 
Multiple sclerosis (MS) is an inflammatory and degenerative demyelinating disease of the central nervous system (CNS). It represents the most common inflammatory condition of the CNS and is the second leading cause of disability among young adults ${ }^{1}$. Although the mechanism that triggers the autoimmune disorder remains unclear, the disorder tends to be triggered by environmental factors in genetically susceptible individuals ${ }^{2,3}$.

The natural history of relapsing-remitting MS includes periods of disease exacerbation followed by a progressive period $^{4}$. Clinical phenotypes of bout-onset MS may widely vary: the Expanded Disability Status Scale (EDSS) ${ }^{5}$ and the Multiple Sclerosis Severity Scale (MSSS) ${ }^{6}$ are the most common methods used to quantify disability and the severity of disease progression over time, and the scores can be correlated with clinical, immunological and genetic phenotypes. Previous studies have recently associated various genetic markers with disability progression ${ }^{7.8}$.

Several studies have shown that variations in human leukocyte antigen (HLA) genes, class I or class II, may be correlated with susceptibility to or severity of autoimmune disorders 9 . Associations with HLA-DR15 haplotype (DRB1*1501-DQA1*0102-DQB1*0602) in MS have repeatedly been demonstrated in multiple populations, such as in northern European, African American and African-Brazilian descendants ${ }^{10,11}$. The HLA expression is regulated by the assembly of a transcriptional complex consisting of several different molecules that interact with sequence elements in their promoters. The HLA class II transactivator gene (CIITA in humans and C2TA in mice), loci 16p13, encodes an important transcription factor that has been described as the master control factor of HLA II gene expression ${ }^{12}$. Thus, CIITA is an attractive candidate for genetic studies of autoimmune diseases for which HLA associations have been well established.

Strong evidence for an association of the CIITA $+1614 \mathrm{G} / \mathrm{C}$ (rs4774) missense single nucleotide polymorphism (SNP) with MS in the presence of DRB1*15:01, a wellestablished MS risk allele, has been reported ${ }^{13,14}$. The CIITA $+1614 \mathrm{C}$ variant, located in exon 11, causes an amino acid substitution from glycine to alanine at amino acid position 500. Additionally, the CIITA -168A/G SNP (rs3087456), located in the gene promoter, is also associated with MS susceptibility ${ }^{15}$. In humans, CIITA +1614 C and CIITA -168 G homozygous polymorphic genotypes have been associated with abnormal gene expression in several autoimmune diseases $^{16,17,18,19,20,21}$. The present study is the first to associate these variants with MS severity.

Therefore, the aim of this study was to investigate the association between the CIITA -168A/G (rs3087456) and CIITA $+1614 \mathrm{G} / \mathrm{C}$ (rs4774) SNPs in clinical disability, disease progression and to investigate the clinical responses to first-line treatment with glatiramer acetate (GA) or interferon beta (IFN-b).

\section{METHODS}

\section{Study population and samples}

This retrospective cohort study was conducted according to a predefined protocol. The included patients were followed up at the University Hospital Clementino Fraga Filho, which is a hospital that patients with MS are routinely referred to, for diagnosis and follow-up in the city of Rio de Janeiro. The included patients fulfilled the criteria outlined by McDonald et al., revised in 2010 by Polman et al..22. Patients with comorbidities, other autoimmune diseases and neuromyelitis optica were excluded. For each patient, neurological assessments were performed every three months. The database included the number of relapses, progression of disability and time intervals to reach EDSS scores of 3.0, 6.0, 7.0, 8.0 and 10. We also compared clinical scores with disease duration using the Global MSSS table. Patients with defined slow progressing patterns of MS progression (MSSS-1) were located in the first three deciles of the table with MSSS $<3$; patients with midrate progression (MSSS-2) were located in the deciles $>4$ to $<7$; and patients with a rapidly progressing pattern (MSSS-3) were located in the last three deciles with MSSS $>7$ (modified from Čierny et al. ${ }^{23}$ ). Several criteria defined by Río et al. ${ }^{24}$ were used to classify treatment responses to GA or IFN-b. We defined a nonresponse to treatment as an increase of at least one EDSS step or any relapse within one year of follow-up ${ }^{24,25}$, as these criteria best reflect the clinical evolution of patients. All patients signed an informed consent to undergo a genetic analysis, and the study procedures were reviewed and approved by the National Council for Ethics in Research (CONEP; \#1265) on May 29, 2000.

\section{Genotypic analysis}

Genomic DNA was extracted from blood samples collected on filter paper (Flinders Technology Associates) according to Bereczky et al. ${ }^{26}$, with some modifications. Briefly, each filter paper was transferred to a $1.5 \mathrm{ml}$ tube containing $200 \mu$ lysis buffer (10 mM Tris $\mathrm{pH} 8.0,100 \mathrm{mM} \mathrm{NaCl}$, $10 \mathrm{mM}$ EDTA, pH 8.0, 0.5\% SDS ) and proteinase $\mathrm{K}(5 \mathrm{mg} / \mathrm{ml})$, and the material was incubated at $56^{\circ} \mathrm{C}$ for two hours. Then, $500 \mu \mathrm{l}$ phenol:chloroform:isoamyl alcohol (25:24:1) was added. After gently stirring the tube, the material was centrifuged for two minutes at $10,000 \mathrm{~g}$, and the aqueous phase was transferred to a new tube, to which the same volume of absolute isopropanol was added. The sample was kept on ice for 30 minutes and then centrifuged at 10,000 g for $10 \mathrm{~min}$ utes. The supernatant was discarded, and the precipitate was washed with $70 \%$ ethanol and then stored in TE solution at pH 8.0 (10 mM Tris HCl; $1 \mathrm{mM}$ EDTA). The DNA extracts were quantified by spectrophotometry at $260 / 280 \mathrm{~nm}$.

The SNPs investigated in this study, CIITA $-168 \mathrm{~A} / \mathrm{G}$ (rs3087456) and CIITA +1614G/C (rs4774), are detailed in Table 1 and the primer sequences were previously described by Patarroyo et al. ${ }^{27}$. Initially, alleles were identified by PCR amplification with sequence-specific primers using $100 \mathrm{ng}$ of genomic DNA in $10 \mu$ volume reaction using a One Lambda 
Table 1. Polymorphisms analyzed in this study.

\begin{tabular}{lcccc}
\hline Polymorphism & Reference & fHt* & MAF* & Functional position \\
\hline CIITA-168A/G & rs 3087456 & 0.46 & 0.37 & promoter \\
CIITA+1614G/C & rs 4774 & 0.41 & 0.25 & Not synonymous \\
\hline fHt: heterozygosity frequency; MAF: minor allele frequency; *According 1,000 genomes. & & &
\end{tabular}

fHt: heterozygosity frequency; MAF: minor allele frequency; ${ }^{\star A c c o r d i n g ~ 1,000 ~ g e n o m e s . ~}$

Table 2. Allelic and genotypic frequencies of the studied SNPS.

\begin{tabular}{lc}
\hline Genotypes and alleles & $\mathrm{n}(\%)$ \\
\hline CIITA -168A/G (rs3087456) & \\
\hline AA & $96(82)$ \\
AG & $13(11)$ \\
GG & $8(7)$ \\
G allele frequency & 0.12 \\
CIITA +1614G/C (rs4774) & \\
\hline GG & $90(77)$ \\
GC & $17(14)$ \\
CC & $10(9)$ \\
C allele frequency & 0.16 \\
\hline
\end{tabular}

(Canoga Park, USA) kit, according to the manufacturer's recommendations, followed by capillary electrophoresis using an ABI PRISM ${ }^{\circledR} 3500$ Genetic Analyzer (Applied Biosystems, Foster City, USA) and an ABI PRISM BigDye Terminator Cycle Sequencing Ready Reaction kit (Applied Biosystems, Foster City, USA). Sequencing data were used for alignment with the available reference sequences in the National Center of Biotechnology Information (NCBI, USA) database.

\section{Statistical analysis}

Allelic and genotypic frequencies were calculated by direct gene counting. Predictors of MS outcomes according to the time to reach EDSS 3.0 and EDSS 6.0 scores compared with genotypes were evaluated using Kaplan-Meier curves and log rank tests. Patients were allocated to one of three groups according to disease progression rate: MSSS1 was characterized as slow progression, MSSS2 as intermediate progression and MSSS3 as rapid progression, and analyzed by logistic regression. The patients were also classified as responders and nonresponders to drug treatments. The chi-square test or Fisher's test were used to test associations between polymorphisms and drug treatments; p-values $<0.05$ were considered statistically significant, and all statistical analyses were conducted using SPSS software (version 24.0).

\section{RESULTS}

This study included a group of 117 patients (37 men and 80 women) with MS. The mean age was 46 (15-75) years (standard deviation [SD] \pm 11.99 years), and the mean age of disease onset was $30(12-58)$ years $(S D \pm 10.43)$. From the time of diagnosis, patients had a median disease duration of 15 years ( $\mathrm{SD} \pm 8.04$ years) in 2017. The MS cohort comprised 99 relapsing-remitting, 13 secondary-progressive and 5 primary-progressive.

The distributions of allelic and genotypic frequencies of the SNPs CIITA -168A/G (rs3087456) and CIITA +1614G/C (rs4774) in our studied population are shown in Table 2. Frequencies of variant alleles were 0.12 for CIITA $-168 \mathrm{~A} / \mathrm{G}$ and 0.16 for CIITA $+1614 \mathrm{G} / \mathrm{C}$.

No association between the CIITA $-168 \mathrm{~A} / \mathrm{G}$ and CIITA $+1614 \mathrm{G} / \mathrm{C}$ SNPs and possible progression to EDSS $\geq 3$ or EDSS $\geq 6$ was observed in the Kaplan-Meier survival analysis (Figure).

We applied the MSSS value as the most powerful indicator to estimate MS severity in individual patients. As shown in Table 3, a less severe MS course was associated with CIITA -168AA, because the chance of the patient progressing to MSSS2 and MSSS3 decreased by $61 \%$ and $75 \%$ respectively ( $\mathrm{p}<0.0001$ ). Although the CIITA -168GG genotype did not reach statistical significance, it was possible to observe a trend for the more severe phenotype, as this genotype was more frequent in the MSSS2 and MSSS3 groups and had 40\% lower odds ratio to reach a more severe MS course. Thus, the homozygous polymorphic genotype could be associated with MS severity, according to the MSSS.

The CIITA $+1614 \mathrm{GG}$ genotype was also more frequent in the MSSS1 group and associated with a less severe MS course; the chance of the patient progressing to MSSS2 and MSSS3 decreased by $66 \%$ and $75 \%$ respectively ( $<<0.0001$ ). We could not determine a relationship of the variant allele with the severity of the disease. Although less significant, the CIITA +1614 GC was also associated with a less severe MS course and the chance of the patient progressing to MSSS3 decreased $79 \%(p=0.015)$.

We analyzed treatment responses in 107 patients who received regular treatments with GA or IFN-b as a first-line immunomodulating drug for at least one year. Although this study included 117 patients with MS, 10 did not use an immunomodulating drug during the course of this study. According to the definition of responses to treatment, $72.7 \%$ of patients carrying the CIITA -168AG genotype and $75 \%$ carrying the GG genotype were nonresponders. For CIITA $+1614 \mathrm{G} / \mathrm{C}$, only a homozygous polymorphic genotype $(66.7 \%$ of patients carrying $\mathrm{CC}$ ) had a worse response than patients carrying a normal genotype (Table 4). However, it was not possible to observe significant differences between the groups. 
A

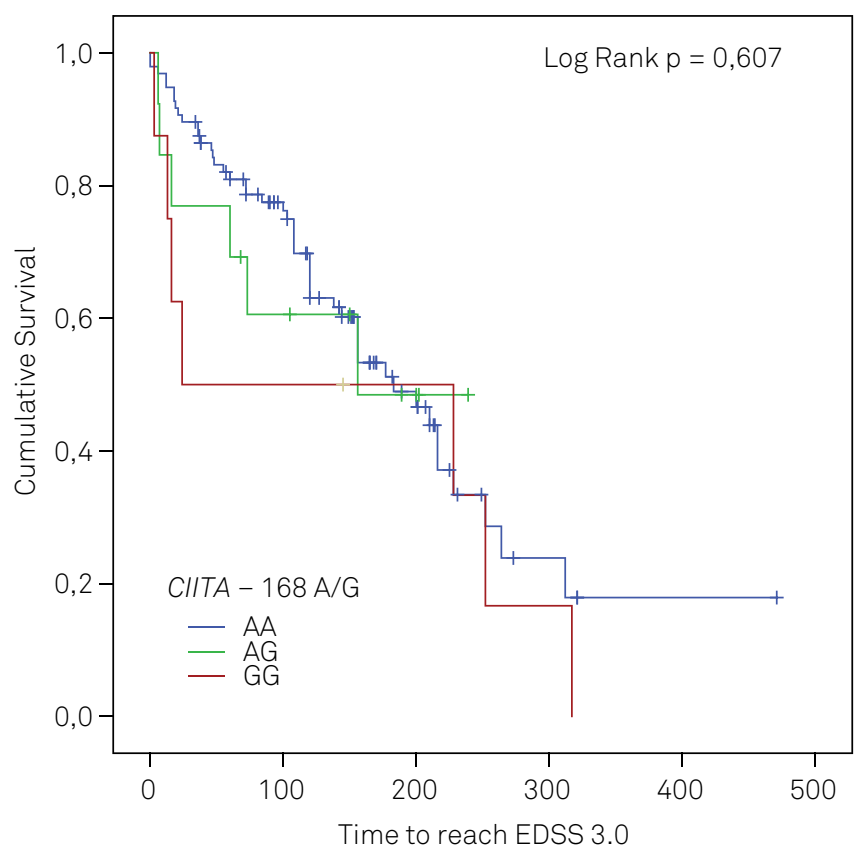

C

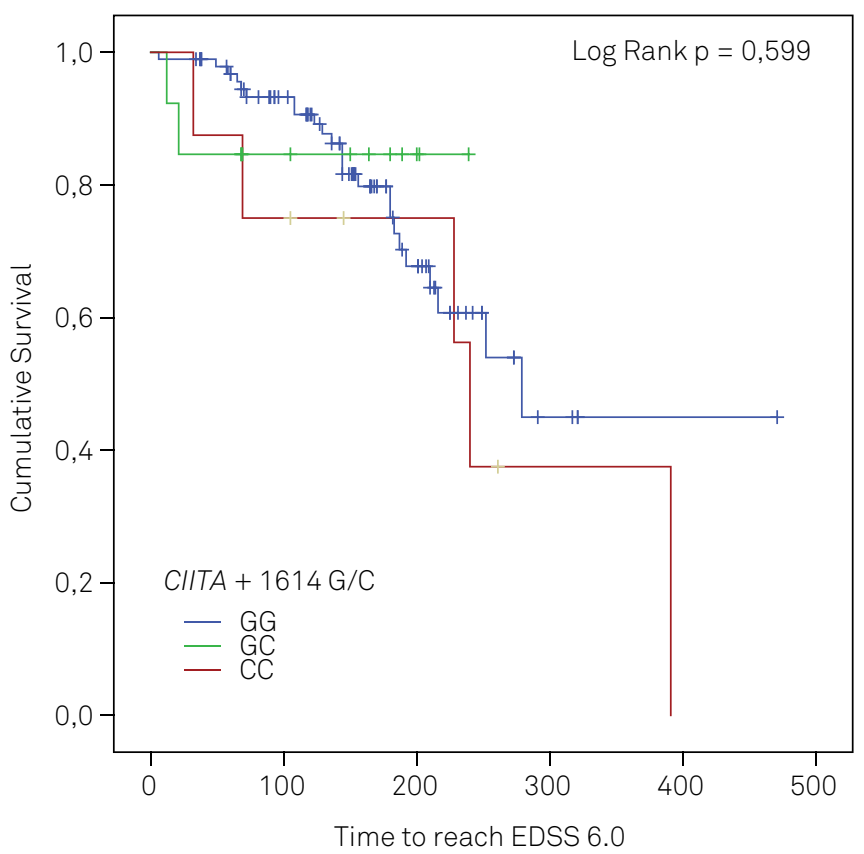

B

Survival Functions

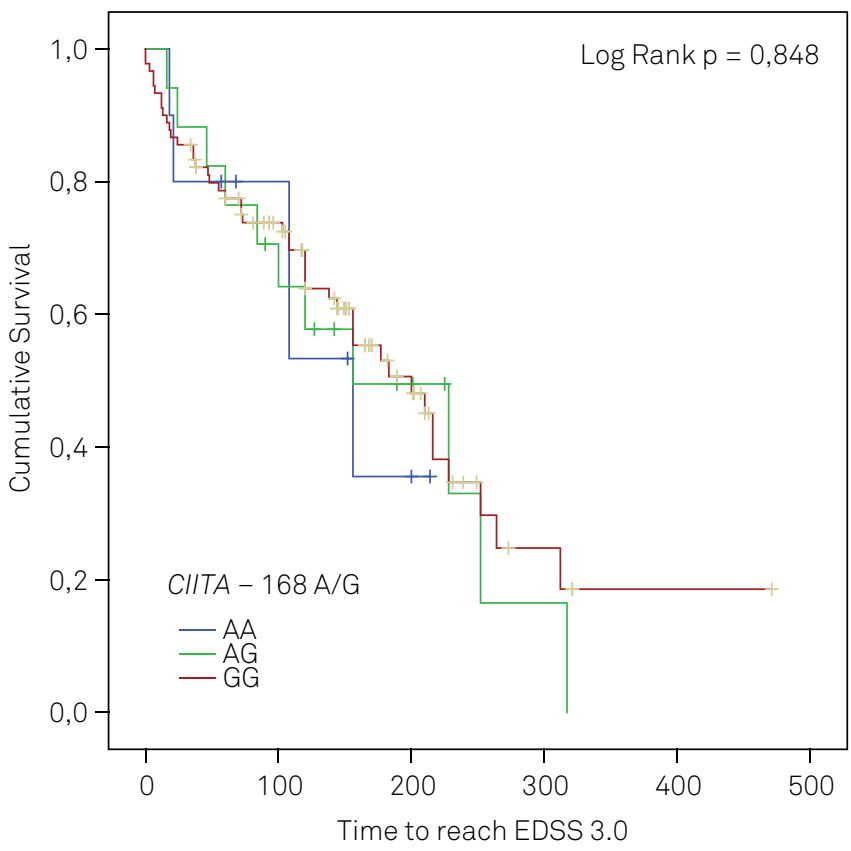

D

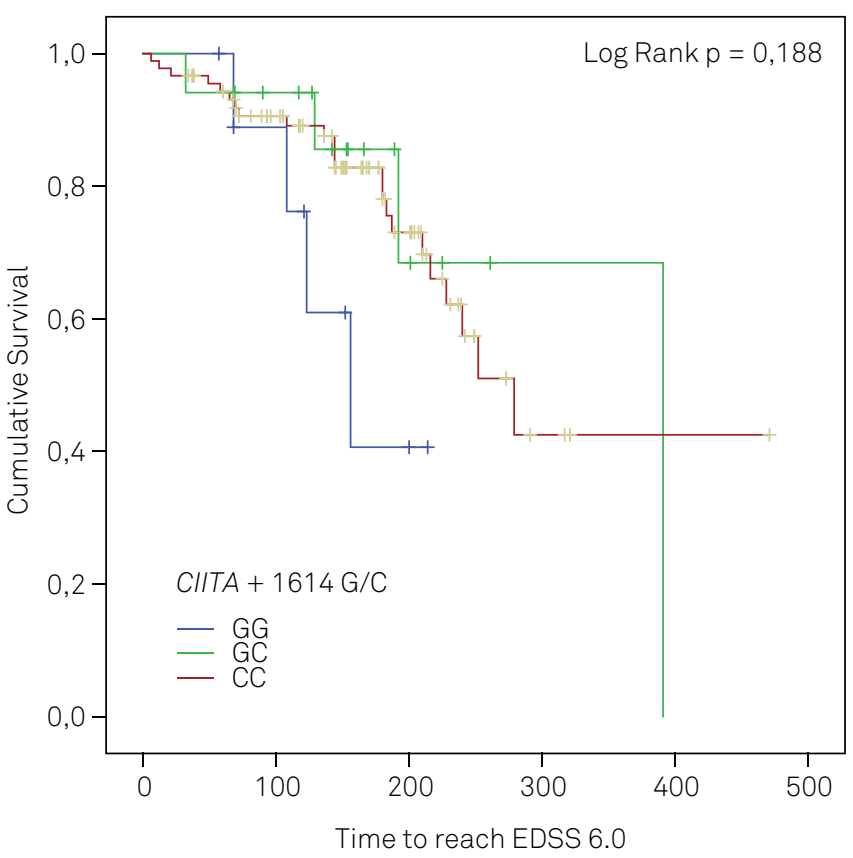

Figure. Survival curves in relation to the variants and the time to reach the two disability milestones (EDSS 3.0 and EDSS 6.0): A) CIITA rs3087456 (-168A/G); B) CIITA rs4774 (+1614G/C).

\section{DISCUSSION}

The characteristics of the MS patients included in this paper are representative of the neurological phenotypes reported by other MS cohort studies in the city of Rio de Janeiro, Brazil, such as female prevalence, highest frequency relapsing-remitting MS, low frequency of progressive course, and African-descendants representing one third of the patients $^{10}$. In this study, we investigated the correlations among polymorphisms, disease course, disease morbidity and therapeutic responses.

We describe here, for the first time, the correlation between SNPs in CIITA and disease severity in a Brazilian cohort. We showed that MSSS values tended to be higher for patients who carried the CIITA -168 GG genotype. In fact, all genome-wide association studies have corroborated the 
Table 3. Polymorphisms and MSSS.

\begin{tabular}{|c|c|c|c|c|c|c|c|}
\hline Variable & n (\%) & MSSS1 (\%) & $p$-value (OR) & MSSS2 (\%) & $p$-value (OR) & MSSS3 (\%) & $p$-value (OR) \\
\hline \multicolumn{8}{|c|}{ rs3087456 (-168A/G) } \\
\hline AA & $96(82)$ & $50(42.8)$ & $0.683(1.09)$ & $27(23)$ & $<0.0001(0.39)$ & $19(16.2)$ & $<0.0001(0.25)$ \\
\hline$A G$ & $13(11.1)$ & $7(5.9)$ & $0.782(1.17)$ & $3(2.6)$ & $0.067(0.30)$ & $3(2.6)$ & $0.067(0.30)$ \\
\hline GG & $8(6.9)$ & $2(1.7)$ & $0.178(0.33)$ & $3(2.6)$ & $0.484(0.60)$ & $3(2.6)$ & $0.484(0.60)$ \\
\hline Overall & $117(100)$ & $59(50.4)$ & & $33(28.2)$ & & $25(21.4)$ & \\
\hline \multicolumn{8}{|c|}{ rs4774 (+1614G/C) } \\
\hline$G G$ & $90(77)$ & $49(41.9)$ & $0.400(1.20)$ & $23(19.7)$ & $<0.0001(0.34)$ & $18(15.4)$ & $<0.0001(0.25)$ \\
\hline GC & $17(14.5)$ & $6(5.1)$ & $0.232(0.55)$ & $8(6.8)$ & $0.808(0.89)$ & $3(2.6)$ & $0.015(0.21)$ \\
\hline $\mathrm{CC}$ & $10(8.5)$ & $4(3.4)$ & $0.530(0.67)$ & $2(1.7)$ & $0.079(0.25)$ & $4(3.4)$ & $0.530(0.67)$ \\
\hline Overall & $117(100)$ & $59(50.4)$ & & $33(28.2)$ & & $25(21.4)$ & \\
\hline
\end{tabular}

OR: odds ratio. Statistical analysis performed with respect to each genotype and frequency in MSSS1, MSSS2 and MSSS3 groups. Statistical significance $(p<0.05)$. Logistic regression.

Table 4. Responder and nonresponder status.

\begin{tabular}{|c|c|c|c|c|c|c|c|c|}
\hline \multirow{4}{*}{$1^{\text {st }}$ Treatment } & \multirow{4}{*}{$\begin{array}{c}\text { Patients } \\
\text { n (\%) }\end{array}$} & \multicolumn{7}{|c|}{ Polymorphism } \\
\hline & & \multirow{3}{*}{$\mathrm{R}$ and $\mathrm{NR}$} & \multicolumn{3}{|c|}{ rs3087456 (-168A/G) } & \multicolumn{3}{|c|}{ rs4774 (+1614G/C) } \\
\hline & & & \multicolumn{3}{|c|}{$\mathrm{n}(\%)$} & \multicolumn{3}{|c|}{$\mathrm{n}(\%)$} \\
\hline & & & AA & $A G$ & GG & GG & $\mathrm{GC}$ & $\mathrm{CC}$ \\
\hline \multirow{3}{*}{ GA or IFN-b } & \multirow{3}{*}{107} & $\mathrm{R}$ & $40(45.5)$ & $3(27.3)$ & $2(25)$ & $35(43.2)$ & $7(41.2)$ & $3(33.3)$ \\
\hline & & \multirow[t]{2}{*}{ NR } & \multirow[t]{2}{*}{$48(54.5)$} & \multirow[t]{2}{*}{$8(72.7)$} & $6(75)$ & \multirow[t]{2}{*}{$46(56.8)$} & \multirow[t]{2}{*}{$10(58.8)$} & $6(66.7)$ \\
\hline & & & & & $p=0.376$ & & & $p=0.943$ \\
\hline \multirow{2}{*}{ Glatiramer acetate } & \multirow{2}{*}{$25(23.4)$} & $\mathrm{R}$ & $5(27.8)$ & $1(16.7)$ & 0 & $5(25)$ & $1(33.3)$ & 0 \\
\hline & & NR & $13(72.2)$ & 5 (83.3) & $1(100)$ & $15(75)$ & $2(66.7)$ & $2(100)$ \\
\hline \multirow{2}{*}{ Interferon-b } & \multirow{2}{*}{$82(76.6)$} & $\mathrm{R}$ & $35(50)$ & $2(40)$ & $2(28.6)$ & $30(49.2)$ & $6(42.9)$ & $3(42.9)$ \\
\hline & & NR & $35(50)$ & $3(60)$ & $5(71.4)$ & $31(50.8)$ & $8(57.1)$ & $4(57.1)$ \\
\hline
\end{tabular}

*Statistical significance $(p<0.05)$. Fisher's test (groups with $n<5)$ and $X^{2}$ test. R: responder; NR: nonresponder.

role of major histocompatibility complex (MHC) genes in MS susceptibility ${ }^{28}$. Moreover, CIITA is referred to as the "master control factor" for expression of the MHC class II gene ${ }^{29}$ and restores expression of all MHC class II isotypes in mutant cells. ${ }^{30}$ The primary function of CIITA is the complete or partial control of the expression of multiple genes involved in antigen presentation to $\mathrm{T}$ cells by MHC molecules, which is essential for an adaptive immune response $\mathrm{e}^{29,30}$. George et al. analyzed 52 independent non-MHC genome-wide association study SNP variants in 7,125 MS patients and found no association with MSSS disease severity ${ }^{8}$. Based on this context, we hypothesized that CIITA could be a candidate gene for determining MS disease severity. Using a retrospective cohort of 117 patients with a 15-year mean disease duration, we found that the distributions of allelic and genotypic frequencies of the CIITA $-168 \mathrm{~A} / \mathrm{G}$ and CIITA $+1614 \mathrm{G} / \mathrm{C}$ SNPs presented the highest frequency in wild type subjects. Although several case-control studies have evaluated the genetic association of SNPs in the CIITA gene in relation to MS development $t^{13,14,31-35}$, none have evaluated whether these variants are related to clinical disability, progression or treatment responses. Considering the influence of CIITA protein in MHC class II expression, CIITA could potentially influence MS severity.

The demographic and clinical parameters showed that MS is typically diagnosed in the second or third decade of life, and the clinical course of MS (conversion to active disease, relapse or disability progression) was previously analyzed by Pan et al. 7 . Weinshenker showed that the median time for MS conversion to a progressive course was approximately ten years ${ }^{36}$. In the last years, the availability of disease-modifying drugs and escalation to higher potency therapies may have changed the natural history of disease and evolution to secondary-progressive MS has become substantially lower ${ }^{37}$. In this context, identifying predictive factors is critical for diagnosing the impact on the disease progression. Although not available for clinical use, biomarkers, such as serum neurofilament light, can monitor tissue damage and the effects of therapies in MS patients ${ }^{38}$. The association of SNPs with MS and markers of disease progression, such as the time to reach disability milestones (EDSS 3.0, 6.0, 7.0, 8.0 and 10) or the time to secondary progression in MS patients, has only been considered in a few genetic studies such as that reported by Pan et al.7, who 
identified three non-HLA SNPs that predicted MS conversion after an episode of clinical isolated syndrome and seven non-HLA SNPs that were correlated with faster progression based on the EDSS. Lin et al. investigated the MS clinical course and found SNPs that predicted 25-hydroxyvitamin D levels and disease relapses. They found significant associations of five SNPs with increased frequency of relapses but no association with disease disability risk associated with the clinical course $\mathrm{e}^{39}$.

We observed significant decreases in the frequency of a wild-type genotype for both CIITA $+1614 \mathrm{G} / \mathrm{C}$ and CIITA $-168 \mathrm{~A} / \mathrm{G}$ in the MSSS2 and MSSS3 groups. Furthermore, we observed a trend of homozygous polymorphic genotype to progress to the MSSS2 or MSSS3 severity groups for the CIITA -168A/G SNP (Table 3). Considering these data, we believe that the polymorphic allele may be associated with MS severity measured by the MSSS.

The CIITA gene is controlled by several distinct promoters, two of which direct specific constitutive expression in dendritic cells (promoter I) and B lymphocytes (promoter III), while another mediates IFN- $\gamma$-induced expression (promoter IV) ${ }^{33,40}$. Masternak et al. ${ }^{12}$ observed that cellular, temporal and functional diversity in MHC-II expression is not regulated at the level of MHC-II genes themselves but is ultimately under the control of several promoter sequences that differentially activate the same transactivator gene ${ }^{40}$. Swanberg et al. ${ }^{17}$ and Martínez et al. ${ }^{33}$ compared MHC molecules with other SNPs and found an association of the $-168 \mathrm{~A} / \mathrm{G}$ polymorphism (rs3087456) with low expression of MHC molecules and susceptibility to MS and another disease with inflammatory components in Nordic countries. Thus, the polymorphic allele could be associated with MS severity based on the MSSS. Rasmussen et al. ${ }^{31}$ studied 111 MS patients and 105 controls from the UK and identified an association of the -168A/G SNP with primary progressive MS ( $p<0.04)$.

Among 107 patients receiving GA or IFN-b treatment in our study, we found that those who carried the CIITA -168AG or GG genotype and the CIITA +1614CC genotype had the most negative influence on the treatment, compared with patients carrying a normal genotype. An association of this polymorphism with a worse treatment response was observed, but without statistical significance, possibly due to the small cohort of patients. We cannot compare this result with other studies because treatment responses including CIITA SNPs have not previously been analyzed. Previous studies that have investigated the therapeutic responses to IFN-b for MS treatment did not find an association with class II and class I alleles. Fernández et al. ${ }^{41}$ did not find an association between HLA class II alleles and therapeutic responses. Swanberg et al. ${ }^{17}$ observed a lower expression of this gene in cells of individuals with the CIITA-168GG genotype than in cells of individuals with other genotypes, after stimulation with IFN-g. Additionally,
Dominguez-Mozo et al. ${ }^{42}$ found that patients with a polymorphic allele of CIITA $+1614 \mathrm{C}$ exhibited significantly higher expression of mRNA levels ${ }^{42}$. Thus, as these SNPs induce variations in gene expression compared with wildtype genotypes, we suggest that changes should be made in the therapy applied to individuals carrying at least one polymorphic allele.

In a study of 195 MS cases and 195 healthy controls from Spain, Garcia-Montojo et al..$^{35}$ analyzed the association of human herpes virus 6 (HHV-6) and two CIITA polymorphisms (rs3087456G and rs4774C). They found a strong association of the CIITA $+1614 \mathrm{C}$ allele with HHV-6 positive MS patients. Upon analyzing the clinical response to IFN-b, only 13/61 (21.3\%) MS patients with the CIITA $+1614 \mathrm{C}$ allele were considered to be clinical responders, while 49/136 (36.1\%) of MS patients with the CIITA $+1614 \mathrm{G}$ allele were clinical responders $(\mathrm{p}=0.004)$. In accordance with our study, (Table 4), 33.3\% of patients carrying CIITA+1614CC genotype (homozygous polymorphic) were clinical responders, while 43.2\% MS patients with the CIITA +1614GG genotype were clinical responders. However, Alvarez-Lafuente et al. ${ }^{34}$ did not find any significant association for the CIITA -168 allele. Improving our knowledge of the stages and mechanisms associated with MS will enable the further development of therapeutic drugs that can target these disease-related mechanisms and allow us to establish a therapeutic window of opportunity for early intervention in nonresponders ${ }^{43}$.

We did not find significant differences between genotypes and the time taken to reach EDSS 3.0 or EDSS 6.0. The frequency results and statistical analysis may be limited by the small sample size, although this was a pilot study that tested the potential association of these CIITA gene SNPs with clinical disability and treatment responses. Indeed, a future study incorporating a larger population may have greater statistical relevance.

In conclusion, our findings support an association between the CIITA -168AA genotype with a less severe MS clinical course, and CIITA -168GG genotype with a more severe MS clinical course. The CIITA +1614 GG and, less significantly, the CIITA +1614 GC were also associated with a less severe MS clinical course. Comprehensive studies conducted across different populations are required to validate these results. These findings may contribute to a better understanding of the clinical course of MS and lead to decreased morbidity and mortality through risk assessment and improvements in therapeutic interventions.

\section{Acknowledgments}

The authors thank the team at Hospital Universitário Clementino Fraga Filho (UFRJ) for help with the sample collection. All authors critically reviewed the manuscript and approved the final version for submission. 
1. Noseworthy JH, Lucchinetti C, Rodriguez M, Weinshenker BG. Multiple sclerosis. N Engl J Med. 2000 Sep;343(13):938-52. https://doi.org/10.1056/NEJM200009283431307

2. Ascherio A, Munger KL, Lünemann JD. The initiation and prevention of multiple sclerosis. Nat Rev Neurol. 2012 Nov;8(11):602-12. https://doi.org/10.1038/nrneurol.2012.198

3. Hillert J. The genetics of multiple sclerosis. Results Probl Cell Differ. 2010;51:1-19. https://doi.org/10.1007/400_2009_13

4. Lublin FD, Reingold SC, Cohen JA, Cutter GR, Sørensen PS, Thompson AJ, et al. Defining the clinical course of multiple sclerosis: the 2013 revisions. Neurology. 2014 Jul;83(3):278-86. https://doi.org/10.1212/WNL.0000000000000560

5. Kurtzke JF. Rating neurologic impairment in multiple sclerosis: an expanded disability status scale (EDSS). Neurology. 1983 Nov;33(11):1444-52. https://doi.org/10.1212/WNL.33.11.1444

6. Roxburgh RH, Seaman SR, Masterman T, Hensiek AE, Sawcer SJ, Vukusic S, et al. Multiple Sclerosis Severity Score: using disability and disease duration to rate disease severity. Neurology. 2005 Apr;64(7):1144-51. https://doi.org/10.1212/01.WNL.0000156155.19270.F8

7. Pan G, Simpson S Jr, Mei I, Charlesworth JC, Lucas R, Ponsonby AL, et al. Role of genetic susceptibility variants in predicting clinical course in multiple sclerosis: a cohort study. J Neurol Neurosurg Psychiatry. 2016 Nov;87(11):1204-11. https://doi.org/10.1136/jnnp-2016-313722

8. George MF, Briggs FB, Shao X, Gianfrancesco MA, Kockum I, Harbo $H F$, et al. Multiple sclerosis risk loci and disease severity in 7,125 individuals from 10 studies. Neurol Genet. 2016 Aug;2(4):e87. https://doi.org/10.1212/NXG.0000000000000087

9. Barcellos LF, Sawcer S, Ramsay PP, Baranzini SE, Thomson G, Briggs F, et al. Heterogeneity at the HLA-DRB1 locus and risk for multiple sclerosis. Hum Mol Genet. 2006 Sep;15(18):2813-24. https://doi.org/10.1093/hmg/ddl223

10. Alves-Leon SV, Papais-Alvarenga R, Magalhães M, Alvarenga M, Thuler LC, Fernández y Fernandez O. Ethnicity-dependent association of HLA DRB1-DQA1-DQB1 alleles in Brazilian multiple sclerosis patients. Acta Neurol Scand. 2007 May;115(5):306-11. https://doi.org/10.1111/j.1600-0404.2006.00750.x

11. Brum DG, Luizon MR, Santos AC, Lana-Peixoto MA, Rocha CF, Brito ML, et al. European ancestry predominates in neuromyelitis optica and multiple sclerosis patients from Brazil. PLoS One. 2013;8(3):e58925. https://doi.org/10.1371/journal.pone.0058925

12. Masternak K, Muhlethaler-Mottet A, Villard J, Zufferey M, Steimle V, Reith W. CIITA is a transcriptional coactivator that is recruited to MHC class II promoters by multiple synergistic interactions with an enhanceosome complex. Genes Dev. 2000 May;14(9):1156-66.

13. Bronson PG, Caillier S, Ramsay PP, McCauley JL, Zuvich RL, De Jager PL, et al.; International Multiple Sclerosis Genetics Consortium. CIITA variation in the presence of HLA-DRB1*1501 increases risk for multiple sclerosis. Hum Mol Genet. 2010 Jun;19(11):2331-40. https://doi.org/10.1093/hmg/ddq101

14. Paradela ER, Alves-Leon SV, Figueiredo AL, Pereira VC, Malfetano F, Mansur LF, et al. The CIITA genetic polymorphism rs $4774 * \mathrm{C}$ in combination with the HLA-DRB1*15:01 allele as a putative susceptibility factor to multiple sclerosis in Brazilian females. Arq Neuropsiquiatr. 2015 Apr;73(4):283-8. https://doi.org/10.1590/0004-282X20150012

15. Liu J, Liu X, Liu Y, Deng S, Huang H, Chen Q, et al. Association of EVI5 rs11808092, CD58 rs2300747, and CIITA rs3087456 polymorphisms with multiple sclerosis risk: A meta-analysis. Meta Gene. 2016 Apr;9:97-103. https://doi.org/10.1016/j.mgene.2016.04.005

16. Sánchez E, Sabio JM, Jiménez-Alonso J, Callejas JL, Camps M, Ramón E, et al. Study of two polymorphisms of the MHC2TA gene with systemic lupus erythematosus. Rheumatology (Oxford). 2008 Jan;47(1):102-3. https://doi.org/10.1093/rheumatology/kem242
17. Swanberg M, Lidman O, Padyukov L, Eriksson P, Akesson E, Jagodic $\mathrm{M}$, et al. MHC2TA is associated with differential MHC molecule expression and susceptibility to rheumatoid arthritis, multiple sclerosis and myocardial infarction. Nat Genet. 2005 May;37(5):48694. https://doi.org/10.1038/ng1544

18. Koizumi K, Okamoto H, likuni N, Nakamura T, Kawamoto M, Momohara S, et al. Single nucleotide polymorphisms in the gene encoding the major histocompatibility complex class II transactivator (CIITA) in systemic lupus erythematosus. Ann Rheum Dis. 2005 Jun;64(6):947-50. https://doi.org/10.1136/ard.2004.025767

19. Lindholm E, Melander O, Almgren P, Berglund G, Agardh CD, Groop L, et al. Polymorphism in the MHC2TA gene is associated with features of the metabolic syndrome and cardiovascular mortality. PLoS One. 2006 Dec;1(1):e64. https://doi.org/10.1371/journal.pone.0000064

20. Orozco G, Robledo G, Linga Reddy MV, García A, Pascual-Salcedo D, Balsa A, et al. Study of the role of a functional polymorphism of MHC2TA in rheumatoid arthritis in three ethnically different populations. Rheumatology (Oxford). 2006 Nov;45(11):1442-4. https://doi.org/10.1093/rheumatology/kel272

21. Martínez A, Sánchez-Lopez M, Varadé J, Mas A, Martín MC, Las Heras $\mathrm{V}$, et al. Role of the MHC2TA gene in autoimmune diseases. Ann Rheum Dis. 2007 Mar;66(3):325-9. https://doi.org/10.1136/ard.2006.059428

22. Polman $\mathrm{CH}$, Reingold SC, Banwell B, Clanet M, Cohen JA, Filippi $\mathrm{M}$, et al. Diagnostic criteria for multiple sclerosis: 2010 revisions to the McDonald criteria. Ann Neurol. 2011 Feb;69(2):292-302. https://doi.org/10.1002/ana.22366

23. Čierny D, Hányšová S, MichalikJ, Kantorová E, Kurča E, Škereňová M, et al. Genetic variants in interleukin 7 receptor $\alpha$ chain (IL-7Ra) are associated with multiple sclerosis risk and disability progression in Central European Slovak population. J Neuroimmunol. 2015 May;282:80-4. https://doi.org/10.1016/j.jneuroim.2015.03.010

24. Río J, Nos C, Tintoré M, Téllez N, Galán I, Pelayo R, et al. Defining the response to interferon-beta in relapsing-remitting multiple sclerosis patients. Ann Neurol. 2006 Feb;59(2):344-52. https://doi.org/10.1002/ana.20740

25. Pereira VC, Malfetano FR, Meira ID, Souza LF, Liem AM, Maiolino A, et al. Clinical response to interferon beta and glatiramer acetate in multiple sclerosis patients: a Brazilian cohort. Arq Neuropsiquiatr. 2012 Oct;70(10):774-9. https://doi.org/10.1590/S0004-282X2012001000005

26. Bereczky S, Mårtensson A, Gil JP, Färnert A. Short report: rapid DNA extraction from archive blood spots on filter paper for genotyping of Plasmodium falciparum. Am J Trop Med Hyg. 2005 Mar;72(3):249-51. https://doi.org/10.4269/ajtmh.2005.72.249

27. Patarroyo JC, Stuve O, Piskurich JF, Hauser SL, Oksenberg JR, Zamvil SS. Single nucleotide polymorphisms in MHC2TA, the gene encoding the MHC class II transactivator (CIITA). Genes Immun. 2002 Feb;3(1):34-7. https://doi.org/10.1038/sj.gene.6363808

28. Hollenbach JA, Oksenberg JR. The immunogenetics of multiple sclerosis: A comprehensive review. J Autoimmun. 2015 Nov;64:13-25. https://doi.org/10.1016/j.jaut.2015.06.010

29. LeibundGut-Landmann S, Waldburger JM, Krawczyk M, Otten LA, Suter T, Fontana A, et al. Mini-review: specificity and expression of CIITA, the master regulator of MHC class II genes. Eur J Immunol. 2004 Jun;34(6):1513-25. https://doi.org/10.1002/eji.200424964

30. Chang $\mathrm{CH}$, Flavell RA. Class II transactivator regulates the expression of multiple genes involved in antigen presentation. J Exp Med. 1995 Feb;181(2):765-7. https://doi.org/10.1084/jem.181.2.765

31. Rasmussen HB, Kelly MA, Clausen J. Genetic susceptibility to multiple sclerosis: detection of polymorphic nucleotides and an intron in the $3^{\prime}$ untranslated region of the major histocompatibility complex class II transactivator gene. Hum Immunol. 2001 Apr;62(4):371-7. https://doi.org/10.1016/S0198-8859(01)00215-4 
32. Akkad DA, Jagiello P, Szyld P, Goedde R, Wieczorek S, Gross WL, et al. Promoter polymorphism rs3087456 in the MHC class II transactivator gene is not associated with susceptibility for selected autoimmune diseases in German patient groups. Int J Immunogenet. 2006 Feb;33(1):59-61. https://doi.org/10.1111/j.1744-313X.2006.00568.x

33. Martínez A, Alvarez-Lafuente R, Mas A, Bartolomé M, García-Montojo $\mathrm{M}$, Las Heras V, et al. Environment-gene interaction in multiple sclerosis: human herpesvirus 6 and MHC2TA. Hum Immunol. 2007 Aug;68(8):685-9. https://doi.org/10.1016/j.humimm.2007.05.005

34. Alvarez-Lafuente R, Martinez A, Garcia-Montojo M, Mas A, Las Heras V, Dominguez-Mozo MI, et al. MHC2TA rs $4774 \mathrm{C}$ and HHV-6A active replication in multiple sclerosis patients. Eur J Neurol. 2010 Jan;17(1):129-35. https://doi.org/10.1111/j.1468-1331.2009.02758.x

35. Garcia-Montojo M, Martinez A, Las Heras V, Dominguez-Mozo MI, Cenit MC, López-Cavanillas M, et al. Herpesvirus active replication in multiple sclerosis: a genetic control? J Neurol Sci. 2011 Dec;311(1-2):98-102. https://doi.org/10.1016/j.jns.2011.09.001

36. Weinshenker BG. The natural history of multiple sclerosis: update 1998. Semin Neurol. 1998;18(3):301-7. https://doi.org/10.1055/s-2008-1040881

37. Cree BA, Gourraud PA, Oksenberg JR, Bevan C, Crabtree-Hartman E, Gelfand JM. Long-term evolution of multiple sclerosis disability in the treatment era. Ann Neurol. 2016 Oct;80(4):499-510. https://doi.org/10.1002/ana.24747
38. Disanto G, Barro C, Benkert P, Naegelin Y, Schädelin S, Giardiello A, et al. Serum Neurofilament light: a biomarker of neuronal damage in multiple sclerosis. Ann Neurol. 2017 Jun;81(6):857-70. https://doi.org/10.1002/ana.24954

39. Lin R, Taylor BV, Simpson S Jr, Charlesworth J, Ponsonby AL, Pittas F, et al. Association between multiple sclerosis risk-associated SNPs and relapse and disability: a prospective cohort study. Mult Scler. 2014 Mar;20(3):313-21. https://doi.org/10.1177/1352458513496882

40. Muhlethaler-Mottet A, Otten LA, Steimle V, Mach B. Expression of MHC class II molecules in different cellular and functional compartments is controlled by differential usage of multiple promoters of the transactivator CIITA. EMBO J. 1997 May;16(10):2851-60. https://doi.org/10.1093/emboj/16.10.2851

41. Fernández O, Fernández V, Mayorga C, Guerrero M, León A, Tamayo JA, et al. HLA class II and response to interferon-beta in multiple sclerosis. Acta Neurol Scand. 2005 Dec;112(6):391-4. https://doi.org/10.1111/j.1600-0404.2005.00415.x

42. Dominguez-Mozo MI, Garcia-Montojo M, De Las Heras V, Garcia-Martinez A, Arias-Leal AM, Casanova I, et al. MHC2TA mRNA levels and human herpesvirus 6 in multiple sclerosis patients treated with interferon beta along two-year follow-up. BMC Neurol. 2012 Sep;12(1):107. https://doi.org/10.1186/1471-2377-12-107

43. Miljković D, Spasojević I. Multiple sclerosis: molecular mechanisms and therapeutic opportunities. Antioxid Redox Signal. 2013 Dec;19(18):2286-334. https://doi.org/10.1089/ars.2012.5068 